\title{
Spring immigration of dragonflies (Odonata) in Tajikistan
}

\section{О весенней иммиграџии стрекоз (Odonata) в Таджикистане}

\author{
A.S. Borisov*, S.N. Borisov** \\ А.С. Борисов*, С.Н. Борисов**
}

Institute of Systematics and Ecology of Animals, Russian Academy of Sciences, Siberian Branch, Frunze Str. 11, Novosibirsk 630091 Russia. E-mails: baswatch@gmail.com*, borisov-s-n@yandex.ru**.

Институт систематики и экологии животных СО РАН, ул. Фрунзе 11, Новосибирск 630091 Россия.

Key words: Odonata, Anax ephippiger, Anax parthenope, Pantala flavescens, Sympetrum fonscolombii, spring immigrations, Tajikistan.

Ключевые слова: Odonata, Anax ephippiger, Anax parthenope, Pantala flavescens, Sympetrum fonscolombii, весенняя иммиграция, Таджикистан.

\begin{abstract}
Four migratory dragonfly species, Anax ephippiger, A. parthenope, Pantala flavescens and Sympetrum fonscolombii, arriving in Tajikistan for reproduction in spring 2019 from southernmost parts of the areal, were studied. In spring, populations of the most abundant and widespread immigrant species, Anax parthenope, presumably include immigrants from both southern and local residents. Ephemeral water ponds, mainly rice fields, are more preferable for oviposition of Pantala flavescens and Sympetrum fonscolombii, and probably typical of Anax ephippiger, but a different type water reservoir is necessary for $A$. parthenope and for a number of local eurytopic non-migrating dragonflies.
\end{abstract}

Резюме. Весной 2019 г. в Таджикистане проведено исследование стрекоз-иммигрантов, которые прилетают сюда для репродукции из расположенных южнее участков ареала. Отмечено 4 таких вида: Anax ephippiger, A. parthenope, Pantala flavescens and Sympetrum fonscolombii. Наиболее широко распространённым и массовым из иммигрантов был $A$. parthenope. Предполагается, что весной в популяциях этого вида одновременно присутствуют и иммигранты, прилетевшие с юга, и резидентные местные особи. Преференции в выборе для яйцекладки эфемерных водоёмов (в первую очередь рисовых полей) наиболее выражены у $P$. flavescens и $S$. fonscolombii и предполагаются у A. ephippiger. A. parthenope, напротив, населяет водоёмы самого разного типа, не отличаясь в этом от эвритопных аборигенных не мигрирующих видов стрекоз.

\section{Introduction}

There are many outstanding issues in the study on the migrations of dragonflies. It is known that in the Northern Hemisphere, some species regularly and seasonally migrate - in spring to the north, in autumn to the south. Moreover, autumn migrations are well-studied, but little is known about spring migrations from the south to the north. Spring flights are barely noticeable and any directional movements of dragonflies (swarms or hordes) have never been visually noted [Russel et al., 1998; Corbet, 1999; May, Mattews, 2008; May, 2013; Borisov, 2015]. Only the use of radar in Bohai Sea of northeastern China made it possible to track down mass spring-summer migrations of Pantala flavescens (Fabricius, 1798) to the north [Feng et al., 2006]. And analysis of isotopic composition of migrants made it possible to prove spring migrations of Anax junius (Drury, 1773) in North America [Hallworth et al., 2018].

In Central Asia, four species of dragonflies are known for seasonal latitudinal migrations: Anax ephippiger (Burmeister, 1839), A parthenope (Selys, 1839), P. flavescens and Sympetrum fonscolombii (Selys, 1840) [Borisov, 2015]. All these species have the extensive ranges covering different natural-climatic zones. For three of them, it is known that in spring already mature individuals arrive to the territory of Central Asia from the more southerly parts of the range, and their summer generations develop here. In autumn, the descendants of immigrants migrate back to the south. This is confirmed by observations on ornithological traps at the Chokpak Pass in South Kazakhstan [Borisov, 2009, 2010, 2015]. Thus, these dragonflies live in Central Asia only during the warm period of the year, and their larvae are unable to hibernate here due to the temperature preferences.

The strategy of the other species, A. parthenope, remains unclear. Obligatory autumn flights of these dragonflies to the south and, at the same time, winter development of larvae on the whole territory of Central Asia (and even further north) suggest that migration strategy of $A$. parthenope is similar to that of $A$. junius in North America. There are cohorts with different annual cycles in populations of this species, one of which migrates and the other one remains residential [May, Mattews, 2008; May, 2013, 2019]. In this case, it is especially difficult to determine the spring immigration of dragonflies, because both aboriginal individuals and immigrants from the south can exist simultaneously in the same locality [Borisov, 2012a, 2015].

At the present time, the most complete data on spring finds of migratory dragonflies are available for Tajikistan, which includes summary data for the second half of the last century [Borisov, 2011a, b, 2012a, b, 2015]. It is interesting to obtain additional information 
about this issue, as well as to identify overall picture of the spring immigration of all migratory species during a particular season.

The results of the study on migratory dragonflies in Tajikistan in spring of 2019 are given below.

\section{Material and methods}

Observation and collecting of migratory dragonflies were conducted from 24 April to 11 May 2019 mainly in the plain and low-mountain areas of south-western and central parts of Tajikistan, as well as in the lower reaches of the Zarafshan Valley in the north-west of the country. The selection of regions was consistent with the main objective of exploring within a short time as much of the territory, where migratory dragonflies could possibly be found. Ponds of various types (lakes, fish ponds, rice paddies, irrigation canals) were explored in 21 localities (Fig. 1).

The species of migratory dragonflies found here are provided for each locality in the list of localities. Indi- viduals of $A$. parthenope, which recently acquired wings, are designated as «post-teneral».

\section{Results}

\section{The list of localities specifying migrant species}

1) 24-25.IV.2019. Nature reserve «Tigrovaya Balka», Lake Dar'yakul' and adjacent desert $37^{\circ} 18^{\prime} 14^{\prime \prime} \mathrm{N}$, 6830'43" E, $338 \mathrm{~m}$ a.s.l. (Fig. 2a). (A. parthenope).

2) 26.IV.2019. Jilikul', fish ponds, $37^{\circ} 32^{\prime} 10^{\prime \prime} \mathrm{N}$, 68 $32^{\prime} 10^{\prime \prime} \mathrm{E}, 350 \mathrm{~m}$ a.s.l. (A. parthenope).

3) 26.IV.2019. Jilikul'-Kumsangir road junction, $37^{\circ} 26^{\prime} 17^{\prime \prime} \mathrm{N}, 68^{\circ} 30^{\prime} 34^{\prime \prime} \mathrm{E}, 340 \mathrm{~m}$ a.s.l. (P. flavescens).

4) 27.IV.2019. Nature reserve «Tigrovaya Balka», Sand Pass, 37 $15^{\prime} 37^{\prime \prime} \mathrm{N}, 68^{\circ} 25^{\prime} 38^{\prime \prime}$ E, $340 \mathrm{~m}$ a.s.l. (Fig. 2b). (A. ephippiger, A. parthenope).

5) 27.IV.2019. Nature reserve «Tigrovaya Balka», Lake Goluboe, $37^{\circ} 12^{\prime} 54^{\prime \prime} \mathrm{N}, 68^{\circ} 21^{\prime} 00^{\prime \prime}$ E, $324 \mathrm{~m}$ a.s.l. (A. parthenope, P. flavescens).

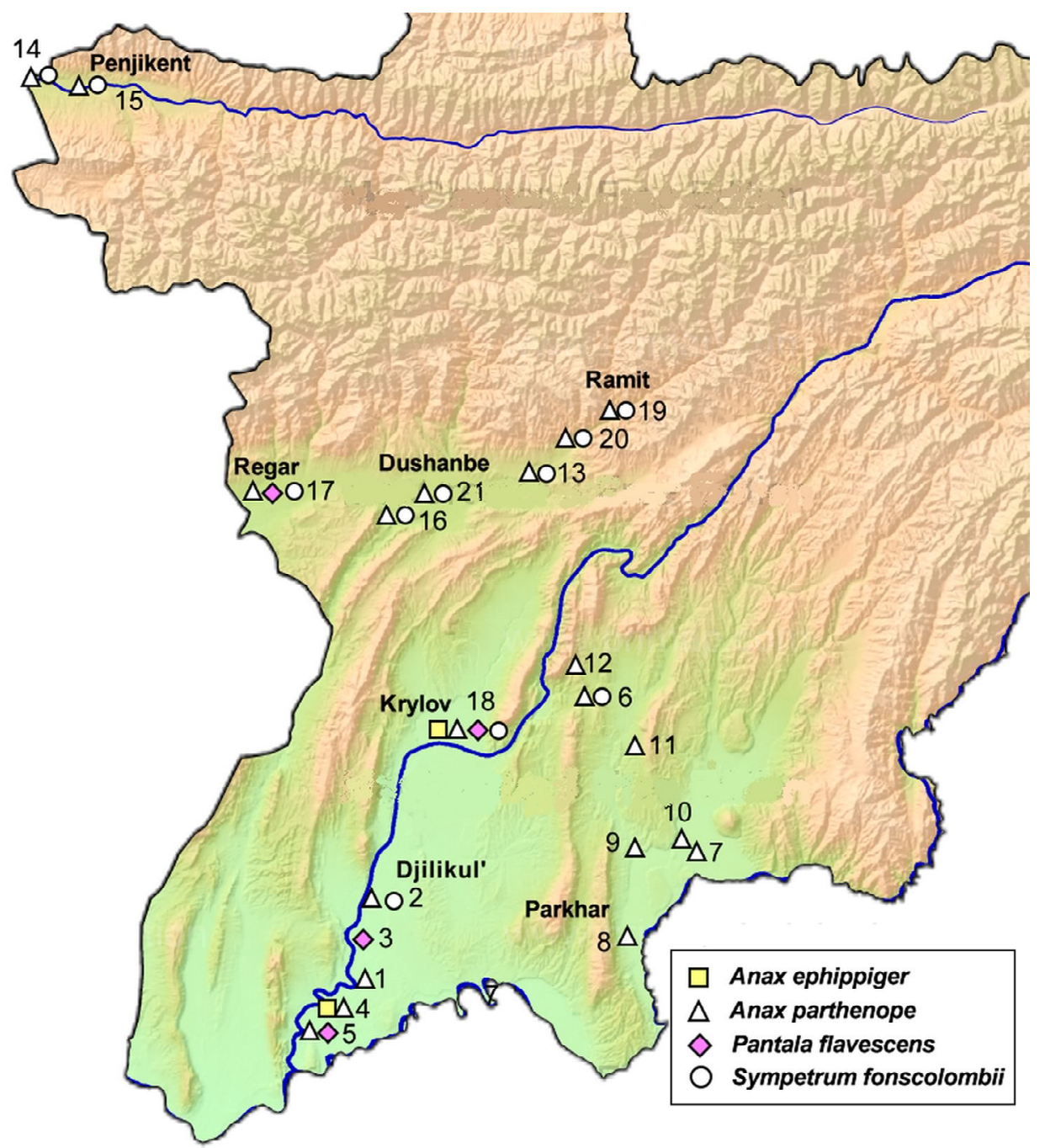

Fig. 1. Locality map of migratory dragonflies in Tajikistan in spring of 2019.

Рис. 1. Карта мест находок стрекоз-иммигрантов в Таджикистане весной 2019 г. 

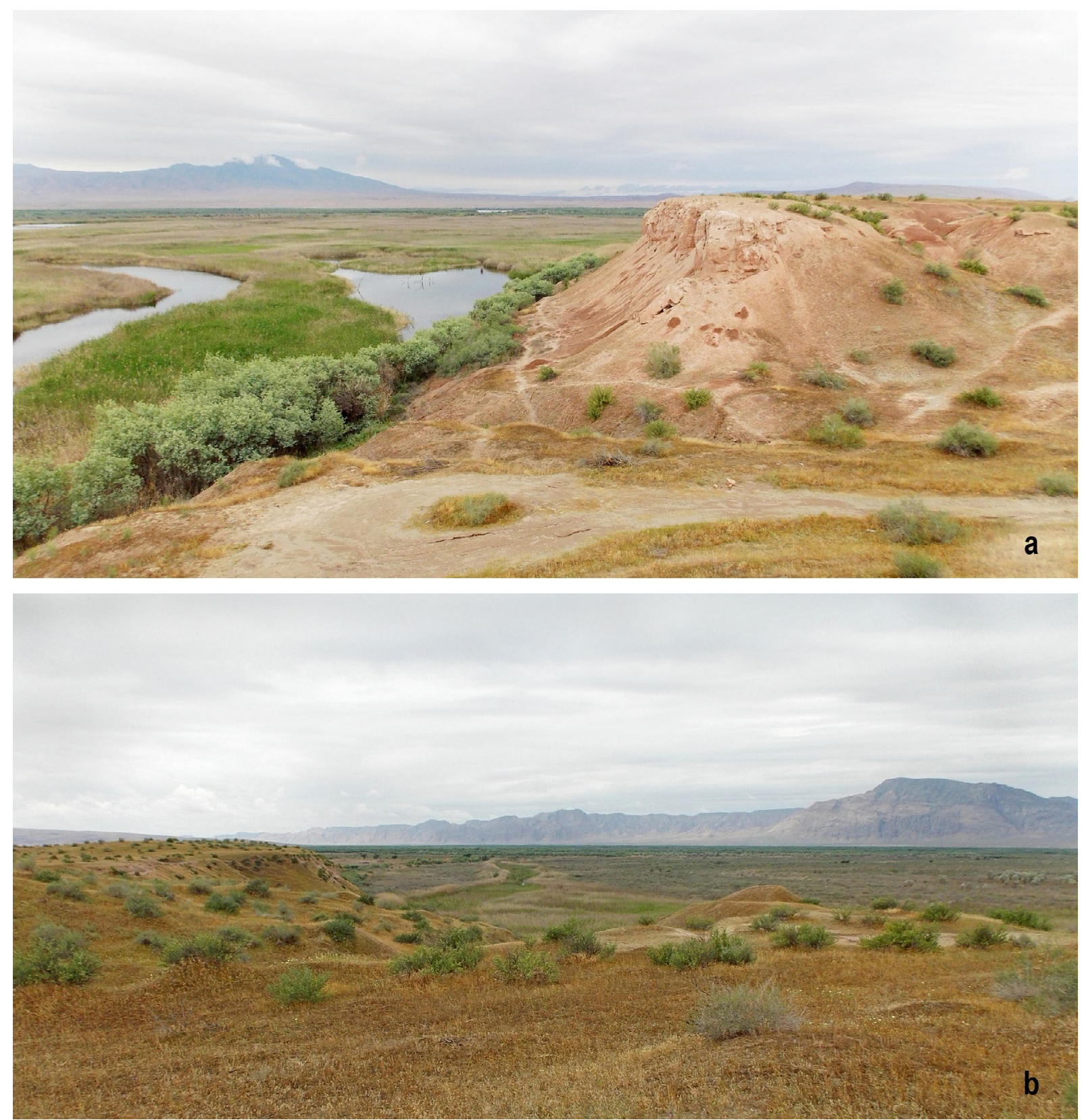

Fig. 2. The localities of concentration of A. parthenope during spring in the desert part of Nature reserve «Tigrovaya Balka» (loc. 1). a - floodplain terrace on the border between desert and riparian areas; $\mathrm{b}$ - semi-fixed sands with shrub vegetation (Salsola and Tamarix).

Рис. 2. Места концентрации А. parthenope в весенний период в пустынной зоне заповедника «Тигровая Балка» (loc. 1). $\mathrm{a}$ - пойменная терраса на границе между пустынной и тугайной зонами; $\mathrm{b}$ - полузакреплённые пески с кустарниковой растительностью (Salsola and Tamarix).

6) 28.IV.2019. Lokhur village, Lake Lyaurkul', $38^{\circ} 01^{\prime} 43^{\prime \prime} \mathrm{N}, 69^{\circ} 12^{\prime} 34^{\prime \prime} \mathrm{E}, 38^{\circ} 01^{\prime} 50^{\prime \prime} \mathrm{N}, 69^{\circ} 12^{\prime} 38^{\prime \prime} \mathrm{E}, 715 \mathrm{~m}$ a.s.1. (Fig. 3a). (A. parthenope, $S$. fonscolombii).

7) 29.IV.2019. Spring river Besh-Kapa and irrigation canals, the surroundings of the village of Kodara, 37³9'37" N, 69³2'13" E, 458 m a.s.l. (Fig. 5). (A. parthenope).

8) 30.IV.2019. The surroundings of Parkhar, Surkhob village, $37^{\circ} 26^{\prime} 53^{\prime \prime} \mathrm{N}, 69^{\circ} 19^{\prime} 15^{\prime \prime} \mathrm{E}, 460 \mathrm{~m}$ a.s.l. (A. parthenope).
9) 30.IV.2019. Spring river Besh-Kapa and irrigation canals, the surroundings of the village of Lenin, 37 $399^{\prime} 31^{\prime \prime}$ N, 69²0'37" E, $455 \mathrm{~m}$ a.s.1. (A. parthenope).

10) 1.V.2019 Kapaly village, irrigation canal, $37^{\circ} 41^{\prime} 05^{\prime \prime} \mathrm{N}, 69^{\circ} 29^{\prime} 24^{\prime \prime} \mathrm{E}, 470 \mathrm{~m}$ a.s.l. (A. parthenope).

11) 1.V.2019. The neighborhood of the village of Bul'en, 375'41" N, 69²0'52" E, 670 m a.s.1. (A. parthenope).

12) 1.V.2019. Ridge Sarsaryak, Ekizak village (Khurchashma), warm creek, 38०06'36" N, 6909'52" E, 950$1100 \mathrm{~m}$ a.s.l. (A. parthenope). 

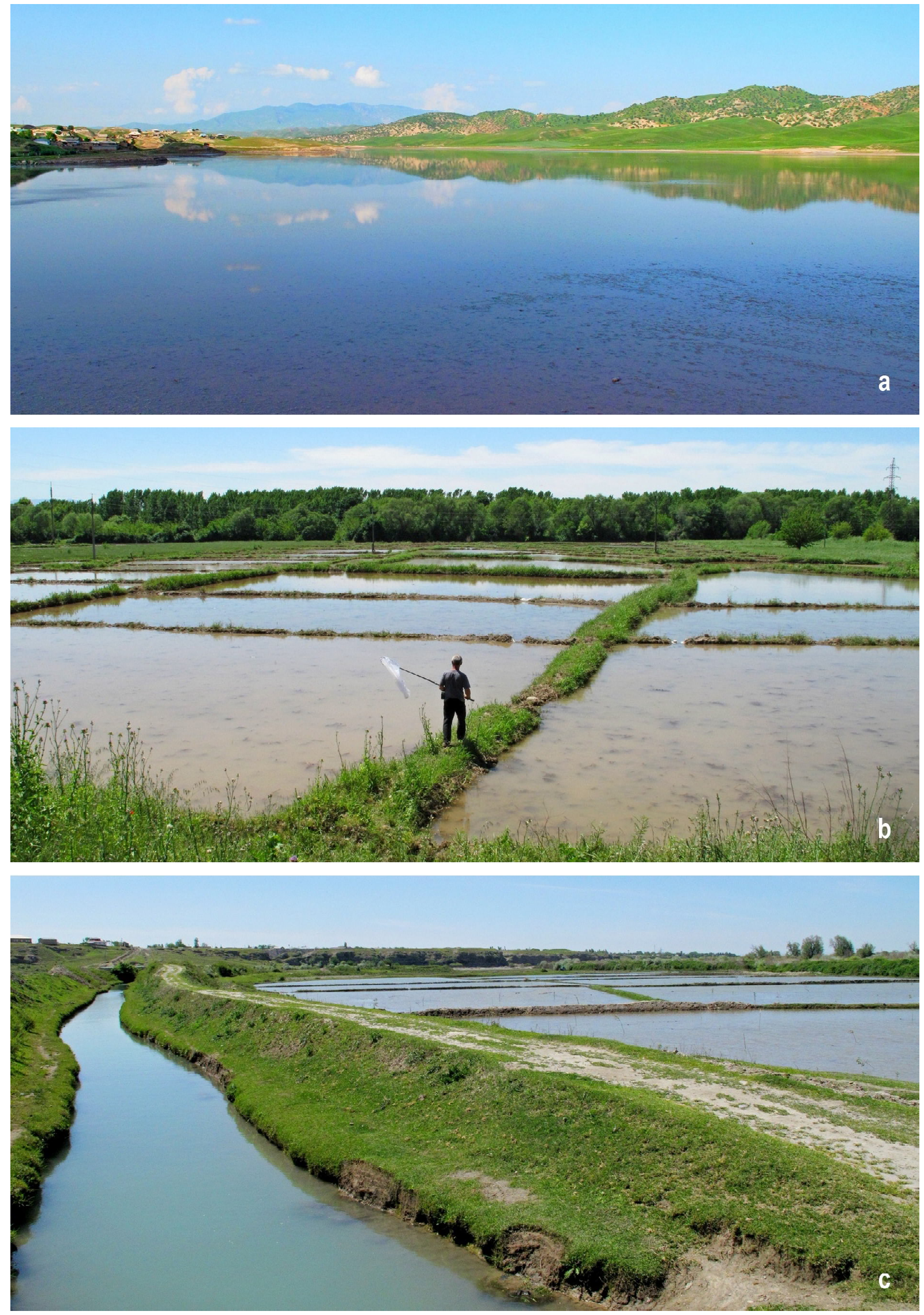
13) 2.V.2019. The surroundings of the city of Vakhdat, fish ponds, $38^{\circ} 34^{\prime} 11 \mathrm{~N}, 69^{\circ} 01^{\prime} 29^{\prime \prime} \mathrm{E}, 872 \mathrm{~m}$ a.s.l. (A. parthenope, S. fonscolombii).

14) 4.V.2019. Village Sarazm, rice paddy, $39^{\circ} 31^{\prime} 18^{\prime \prime} \mathrm{N}$, $67^{\circ} 25^{\prime} 44^{\prime \prime}$ E, $880 \mathrm{~m}$ a.s.1. (Fig. $3 \mathrm{~b}$ ). (A. parthenope, $S$. fonscolombii).

15) 4-5.V.2019. The surroundings of the city of Penjikent, rice paddy, $39^{\circ} 30^{\prime} 28^{\prime \prime} \mathrm{N}, 67^{\circ} 35^{\prime} 41^{\prime \prime} \mathrm{E}, 950 \mathrm{~m}$ a.s.l. (Fig. 3c). (A. parthenope, S. fonscolombii).

16) 6.V.2019. The surroundings of the Gissar Fortress, 38 $27^{\prime} 59^{\prime \prime} \mathrm{N}, 6^{\circ} 35^{\prime} 28^{\prime \prime} \mathrm{E}, 695 \mathrm{~m}$ a.s.l. (A. parthenope).

17) 6, 11.V.2019. Regar (modern Tursunzoda) neighborhood, rice paddy, 38 31'51" N, 68 $13^{\circ} 08^{\prime \prime} \mathrm{E}, 732 \mathrm{~m}$ a.s.l. (A. parthenope, P. flavescens, S. fonscolombii).

18) 07-08.V.2019. The surroundings of the village of Krylov, flooded fields, fish ponds, irrigation canals, $37^{\circ} 54^{\prime} 41^{\prime \prime} \mathrm{N}, 68^{\circ} 49^{\prime} 46^{\prime \prime} \mathrm{E}, 431 \mathrm{~m}$ a.s.1. (A. ephippiger, $A$. parthenope, $P$. flavescens, $S$. fonscolombii).

19) 9.V.2019. Village Ramit, $38^{\circ} 43^{\prime} 41^{\prime \prime}$ N, 69¹9'18" E, 1195 m a.s.l. (A. parthenope, S. fonscolombii).

20) 9.V.2019. Ramit gorge, Yos, trout ponds, 38³9'32" N, $69^{\circ} 10^{\prime} 41^{\prime \prime}$ E, $1025 \mathrm{~m}$ a.s.1. (A. parthenope, S. fonscolombii).

21) 10.V.2019. Dushanbe, Lake Career, 38³0'41" N, 68 43'51"E, $730 \mathrm{~m}$ a.s.1. (A. parthenope, S. fonscolombii).

\section{The list of migrant species}

Anax ephippiger. Localities: 4 (one individual visually), 18 ( 3 pairs in copuli visually).

The species was noted only in two localities of the Vakhshskaya Valley. On 27 April, the only individual was observed in the swarm of $A$. parthenope in the desert part of Nature reserve «Tigrovaya Balka» (loc. 4). On 8 May, one more observation of these dragonflies took place (loc. 18). From 10 a.m. to 1 p.m., three flying pairs in copuli were noted on flooded field.

Anax parthenope. Localities: 1 (16 $\sigma^{\top} \sigma^{\top}, 7$, + , «old» individuals with shabby wings (Fig. 4a)), $10^{7}, 2$, + postteneral), 2-12 (visualy), 13 (10 post-teneral), 14-17 (visually), 18 (10 post-teneral), 19-20 (visually), 21 (10 post-teneral).

The species was noted in all explored localities. Massive swarms of these dragonflies were observed in the desert part of Nature reserve «Tigrovaya Balka» (loc. 1, 4) (Fig. 2). When it rained, it was easy to handpick dragonflies hiding among the bushes (Salsola and Tamarix). The majority of viewed individuals (more than 50) looked very «old» and had shabby wings, reflecting the prolonged period of their existence in the imaginal phase (Fig. 4a, b). Individuals, which recently acquired sparkly and uninjured wings, were seen much less frequently. Copulating pairs of $A$. parthenope were often noted in the desert at a distance from ponds. Reproductive behavior (coupling and oviposition) were observed on ponds of various types (lakes, rice paddies, fish ponds, irrigation canals).

Pantala flavescens. Localities: 3 (one individual visually), 5 (one individual visually), 17 (2 $\sigma^{\top} \sigma^{7}, 1+$, 06.V.2019; $\left.70^{7} \sigma^{7}, 11 . V .2019\right), 18(19)$.

In late April, only two individuals were observed in the south of the Vakhshskaya Valley. In the first decade of May, the species was already common in all studied rice paddies in the vicinity of Regar in Gissar Valley (loc. 17). Oviposition of these dragonflies was also observed here. But at the same time, on 4 and 5 May, these dragonflies were absent in rice paddies of the Zarafshan Valley (loc. 14, 15).

Sympetrum fonscolombii. Localities: 2 (visually), 6

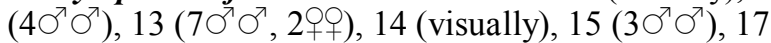

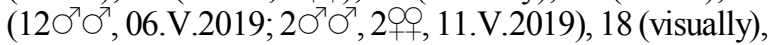
$19\left(3 \sigma^{7} \sigma^{7}\right), 20$ (visually), 21 (19).

All viewed individuals were «old». Their coloring differed from that of insects which recently acquired wings. Males had dark red coloring (Fig. 4c) and females had reddish black, dark olive green coloring.

The species was the most numerous in rice paddies (loc. 14, 15, 17) (Fig. 3d, c). Also it was observed on fish ponds (loc. 13). The high number and active reproductive behavior were noted on Lake Lyaurkul' (loc. 6) (Fig. $3 a)$. This lake is an extensive $(1.2 \times 0.6 \mathrm{~km})$ ephemeral pond, which dries up in autumn. It is located in intermountain area and is formed by melt-water in spring. The banks of this temporary lake are open. There is no emergent and semi-aquatic vegetation.

\section{Discussion}

In spring of 2019, all 4 species of migratory dragonflies were noted on the studied territory. Their number and nature of distribution were markedly different.

A. ephippiger was the smallest of all migratory species. It was singly observed in two localities. The presence of pairs in copuli indicates the reproductive behavior of these dragonflies.

A. parthenope was a common species everywhere. And also reproductive activity was observed everywhere. Both «old» and recently winged individuals were noted. It seemed that in the swarms of these dragonflies in the desert part of Nature reserve «Tigrovaya Balka», the largest number were migratory dragonflies from the south. Well worn wings of dragonflies can serve as evidence of their long-term migratory activity.

$\boldsymbol{P}$. flavescens was singly noted in the south of the Vakhshskaya Valley in late April. In the first decade of

Fig. 3. Ephemeral ponds, which are oviposition sites of A. parthenope and S. fonscolombii. a - periodically drying up Lake Lyaurkul' (loc. 6); b - rice paddies in the vicinity of Sarazm (loc. 14); c — irrigation canal and rice paddies in the vicinity of Panjakent (loc. 15).

Рис. 3. Эфемерные водоёмы - места яйцекладки A. parthenope and S. fonscolombii. a - периодически пересыхающее озеро Аяуркуль (loc. 6); b - рисовые поля в окрестностях Саразма (loc. 14); с - оросительный канал и рисовые поля в окрестностях Пенджикента (loc. 15). 

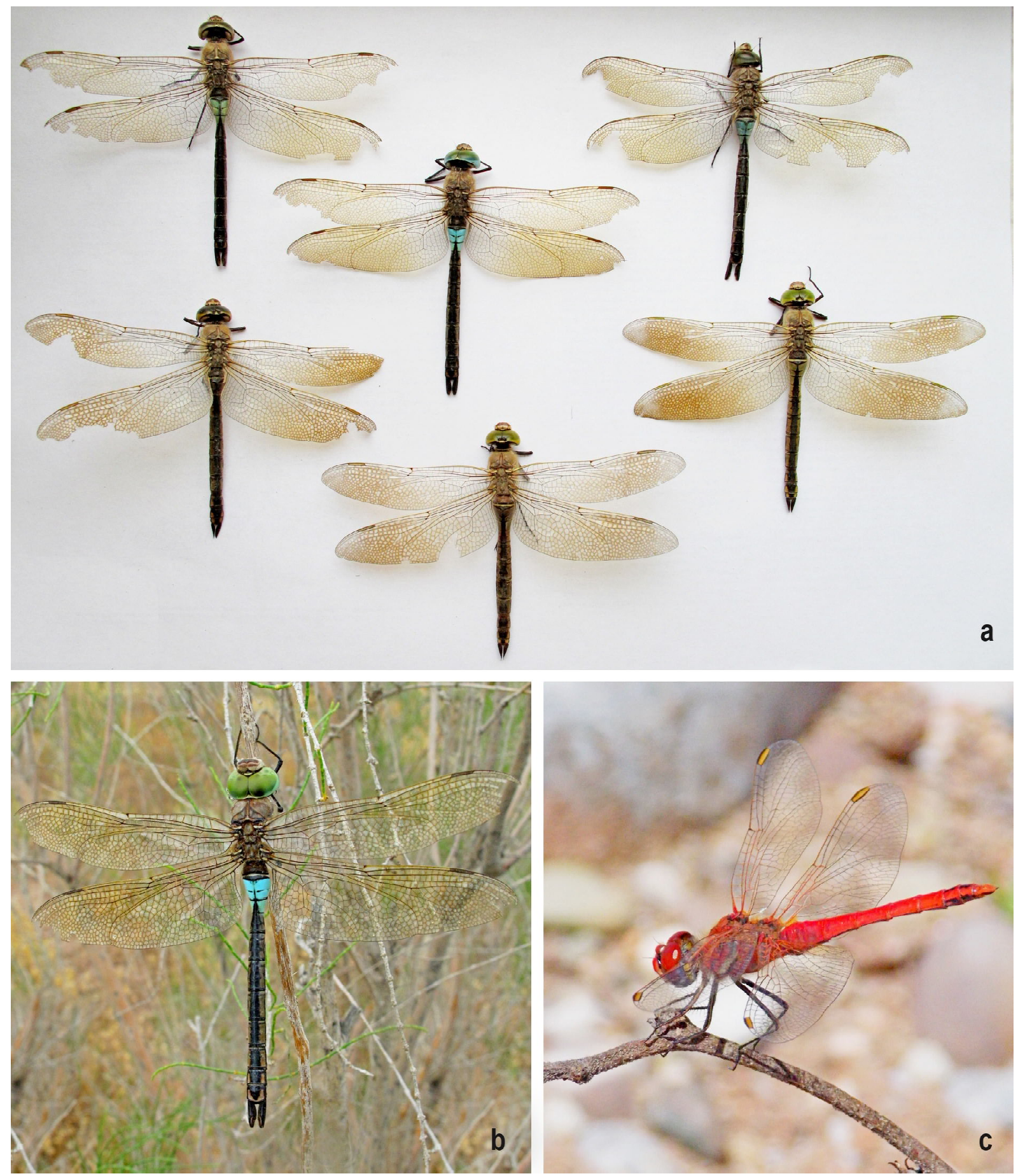

Fig. 4. Migratory dragonflies. a - «old» individuals of A. parthenope collected in the desert part of Nature reserve «Tigrovaya Balka» (loc. 1, 4); b - «old» male of A. Parthenope (loc. 4); c - mature male of S. fonscolombii (loc. 13).

Рис. 4. Стрекозы-иммигранты. а - «старые» особи A. parthenope, собранные в пустынной части заповедника «Тигровая Балка» (loc. 1, 4); b - «старый» самец A. parthenope (loc. 4); с - половозрелый самец S. fonscolombii (loc. 13).

May, the species was common in rice paddies of Gissar Valley (Central Tajikistan).

S. fonscolombii, in contrast to the previous species, was rare on the plain area of the south-west of Tajikistan, but was common on submontane and highland areas of central part of the country (above $700 \mathrm{~m}$ a.s.l.), and also in rice paddies of the Zarafshan Valley (above 800 m a.s.l.).

It should be pointed out that at the same time three out of four species (without A. ephippiger) were observed in rice paddies of Gissar Valley (loc. 17). All four migratory species were simultaneously noted in only 
one locality in the northern part of the Vakhshskaya Valley (loc. 18). All of them «appeared» in a small number on the temporary pond immediately after its formation. This is a meadow, which is specially filled with water using irrigation system in order to cut the hay.

It is of interest to note that similar but more outstanding picture of sudden appearance of migratory dragonflies was seen by one of the authors in the same locality in spring of 2014 (unpublished). From 26 to 30 April, there weren't noted any species of migratory dragonflies. On the night of 1 May, plot of the field was flooded due to accidental rush of irrigation canal. And thus, a small temporary pond (approximately $80 \times 30 \mathrm{~m}$ and with a depth of $0.4 \mathrm{~m}$ ) was formed. The next morning, migratory dragonflies of three species appeared on this pond in large numbers: A. ephippiger, $P$. flavescens and $S$. fonscolombii. Dozens of dragonflies were within eyeshot at the same time. There was pairing and intensive oviposition in all species.

The preferences of migratory dragonflies in the choice of ephemeral ponds for oviposition should be highlighted. Such a strategy undoubtedly has an adaptive significance [May, 2019]. In habitats, where hydrobiocenoses has not yet been established or is in the early stages of formation, the resistance of native biota is minimal and, as a rule, there are no aquatic predators. In this case, rapidly developing larvae of migratory dragonflies gain a competitive advantage. In Tajikistan, the preimaginal development of $P$. flavescens and $S$. fonscolombii takes no more than 2 months on average [Borisov, 2011b, 2012b].

At the same time, it remains a mystery how migratory dragonflies choose the newly formed ponds for oviposition among all the diversity of ponds. One of the visual differences of ephemeral ponds, which can serve as guidance for dragonflies, is the absence or poor development of aquatic and semi-aquatic vegetation, for instance, like in rice paddies after its recent water admission.

P. flavescens [Corbet, 1999; Borisov, 2012b; May, 2013] and S. fonscolombii [Lempert, 1997; Borisov, 2011b; Ikemeyer et al., 2015] have clear preferences in development on ephemeral ponds. These species are common inhabitants of rice paddies in Tajikistan and, in general, Central Asia [Borisov, 2015]. Apparently, $A$. ephippiger has the same preferences in the choice of habitats for larvae [Dumont, Desmet, 1990; Borisov, 2011a]. In contrast to the previous species, A. parthenope inhabits various ponds, not differently from the eurytopic native non-migratory species of dragonflies. On Central Asian plains, it is mostly artificial ponds connected with irrigation system. It is not yet known whether there are differences in preferences in the choice of larval habitats for migratory and residential individuals of $A$. parthenope.

\section{Acknowledgements}

The work was supported by the Russian Foundation for Basic Research (grant No. 18-04-00725-a) and the Federal Fundamental Scientific Research Program for 2013-2020 (No. AAAA-A16-116121410123-1).

\section{References}

Borisov S.N. 2009. Study of dragonflies (Odonata) migrations in the Western Tien-Shan Mountains using ornithological traps // Entomological Review. V.88. No.10. P.1025-1029.

Borisov S.N. 2010. [Autumnal migrations of dragonflies (Odonata) in the Chokpak Pass of West Tien-Shan, observed and actual flight measurements] // Evraziatskii entomologicheskii zhurnal. Vol.9. No.1. P.7-12. [In Russian, with English summary].

Borisov S.N. 2011a. [Migrant dragonflies in Middle Asia. 1. Anax ephippiger (Burmeister, 1839) (Odonata, Aeshnidae)] // Evrasiatskii entomologicheskii zhurnal. Vol.10. No.2. P.125130. [In Russian, with English summary].

Borisov S.N. 2011b. [Migrant dragonflies in Middle Asia. 2. Sympetrum fonscolombii (Selys, 1840) (Odonata, Libellulidae)] // Evraziatskii entomologicheskii zhurnal. Vol.10. No.4. P.415-421. [In Russian, with English summary].

Borisov S.N. 2012a. [Migrant dragonflies in Middle Asia. 4. Anax parthenope parthenope (Selys, 1834) (Odonata, Aeshnidae)] // Evraziatskii entomologicheskii zhurnal. Vol.11. No.3. P.239-248. [In Russian, with English summary].

Borisov S.N. 2012b. [Migrant dragonflies in Middle Asia. 3. Pantala flavescens (Fabricius, 1798) (Odonata, Libellulidae)] // Evraziatskii entomologicheskii zhurnal. Vol.11. No.1. P.37-41. [In Russian, with English summary].

Borisov, S.N. 2015. [Migrations of dragonflies (Odonata) in Central Asia: a review. Part 1. Latitudinal migrations] // Evraziatskii entomologicheskii zhurnal. Vol.14. No.3. P.241256. [In Russian, with English summary].

Corbet Ph.S. 1999. Dragonflies: Behavior and ecology of Odonata. Colchester: Harley Books. 829 p.

Dumont H.J., Desmet K. 1990. Trans-Sahara and transMediterranean migratory activity of Hemianax ephippiger (Burmeister) in 1988 and 1989 (Anisoptera: Aeshnidae) // Odonatologica. Vol.19. P.181-185.

Feng H.-Q., Wu K.-M., Ni Y.-X., Cheng D.-F., Guo Y.-Y. 2006. Nocturnal migration of dragonflies over the Bohai Sea in northern China // Ecological Entomology. Vol.31. P.511-520.

Hallworth M.T, Marra P.P, McFarland K.P, Zahendra S., Studds C.E. 2018. Tracking dragons: stable isotopes reveal the annual cycle of a long-distance migratory insect // Biology Letters. Vol.14. P.1-5.

Ikemeyer D., Schneider E., Schneider J., Schneider T. 2015. Records of Odonata in North-and North-East Iran including Sympecma gobica (Förster, 1900) as a new species for Iran // Entomologische Zeitschrift. Vol.125. No.3. P. 147-152.

Lempert J. 1997. Die Einwanderung von Sympetrum fonscolombii (Selys) nach Mitteleuropa im Jahre 1996 (Anisoptera: Libellulidae) // Libellula. Bd.16. S.143-168.

May M.L. 2013. A critical overview of progress in studies of migration of dragonflies (Odonata: Anisoptera), with emphasis on North America // Journal of Insect Conservation. Vol.17. No.1. P.1-15.

May M.L. 2019. Chapter 3. Dispersal by Aquatic Insects // Aquatic Insects. P.35-72. DOI: 10.1007/978-3-030-16327-3_3.

May M.L., Matthews J.H. 2008. Migration in Odonata: a case study of Anax junius // A. Córdoba-Aguilar (edited): Chapter 6. Dragonflies and Damselflies. Model organisms for ecological and evolutionary research. Oxford University press. P.63-77.

Russell R.W., May M.L., Soltesz K.L., Fitzpatrick J.W. 1998. Massive swarm migrations of dragonflies (Odonata) in eastern North America // American Midland Naturalist. Vol.140. P. 325-342. 